\title{
PLAUČIŲ ULTRAGARSINIO TYRIMO PANAUDOJIMAS COVID-19 SUKELTOS PNEUMONIJOS DIAGNOSTIKAI
}

\author{
Domantas Vingrys ${ }^{1}$, Ugnė Kulnickaité ${ }^{2}$ \\ ${ }^{1}$ Biržu ligonine, ${ }^{2}$ Lietuvos sveikatos mokslu universitetas
}

Raktažodžiai: COVID-19, plaučių ultragarsinis tyrimas, pneumonija.

\section{Santrauka \\ SARS-CoV-2 viruso sukeliama COVID-19 infekcija daž- niausiai pažeidžia kvėpavimo takų sistemą ir pasižymi dideliu užkrečiamumu. Šios priežastys sunkina ligoniu diagnostikos ir transportavimo galimybes, todèl tenka ieškoti alternatyvių diagnostikos būdų, keliančių mažesni infekcijos sklidimo ligoninėse pavojų. \\ Tikslas - išsiaiškinti ultragarso panaudojimo COVID-19 pneumonijos diagnostikai naujoves. \\ Tyrimo medžiaga ir metodai. Naudojantis Science Direct, PubMed duomenų bazėmis, atlikta literatūros apžvalga. Atrinktos publikacijos, kuriose analizuojamas plaučiu ultragarsinio tyrimo panaudojimas COVID-19 sukeltos pneumonijos diagnostikai, radiniai, kitos virusų sukel- tos pneumonijos bei palyginimas su kompiuterine to- mografija. \\ Ultragarsinis tyrimas greitai atliekamas, portabilus, turi tyrimo kartojimo galimybę bei pasižymi dideliu jautrumu plaučių ligų pakitimams. Dẻl šių privalumų ultragarso tyrimas neišvengiamai pradètas naudoti COVID-19 pneu- monijos diagnostikai.}

\section{Ivadas}

SARS-CoV-2 viruso sukeliama COVID-19 infekcija dažniausiai pasireiškia plaučių pažeidimu ir sukelia ūmų respiracinio distreso sindromą, virusinę pneumoniją ir tromboembolines komplikacijas [1]. Nors dažniausiai naudojama pneumonijos vaizdo diagnostikos priemonè yra krūtinės ląstos rengenografija, jos diagnostinè verte labai ribota ir nėra tinkama ligos stebėsenai [2]. Krūtinès kompiuterinè tomografija (KT) yra auksinis standartas COVID-19 sukeltos pneumonijos sunkumui vertinti [3]. Kompiuterinès tomografijos tyrimą sunkina infekcijos plitimo rizika ir logistiniai trukdžiai. Sergančiujų COVID-19 pacientų transportavimo KT tyrimui metu, kyla grèsmé užsikrėsti ligonị transportuo- jančiam personalui ir COVID-19 nesergantiems pacientams. Dẻl minètų priežasčių, krūtinès KT tyrimas atliekamas ne visiems ligoniams [4]. Ši aplinkybe priverte svarstyti plaučių ultragarso (PUG) tyrimo integravimą COVID-19 sukelta pneumonija sergantiems pacientams. Vienas didžiausių šio tyrimo privalumų - galimybè greitai atlikti tyrimą prie paciento lovos, jo netransportuojant. Šio tyrimo metu neskleidžiama jonizuojančioji spinduliuotè. Panašios tendencijos buvo stebimos ir H1N1 viruso epidemijos metu [5].

Tyrimo tikslas - išsiaiškinti ultragarso panaudojimo COVID-19 pneumonijos diagnostikos naujoves.

\section{Tyrimo medžiaga ir metodai}

Naudojantis Science Direct, PubMed duomenų bazèmis, atlikta literatūros apžvalga. Atrinktos publikacijos, kuriose analizuojamas plaučių ultragarsinio tyrimo panaudojimas COVID-19 sukeltos pneumonijos diagnostikai, radiniai, kitos virusų sukeltos pneumonijos bei palyginimas su kompiuterine tomografija.

\section{Tyrimo rezultatai ir jų aptarimas}

Plaučių ultragarso ir krūtinès kompiuterinès tomografijos palyginimas. Viename retrospektyviame tyrime Kinijoje išanalizuota COVID-19 sukelta pneumonija 29 pacientams. Pacientams atlikta po keletą PUG ir krūtinès KT tyrimų 12 valandų intervalais. Pastebètas didelis plaučių ultragarso jautrumas oro (plaučių) skysčio sąsajos pokyčiams, aiškiai parodydamas intersticinę alveolinę pažaidą su intersticiniais eksudatais ir edema, sukelta COVID-19. PUG parodè didesnį jautrumą, nei krūtinès KT, atpažįstant alveolines ir intersticines patologijas, konsolidacijas ir pleuros efuziją [6]. Kitame tyrime, atliktame A. Nouvenne ir kt., buvo vertinama koreliacija tarp ultragarso ir krūtinès KT tyrimo. Autoriai retrospektyviai apžvelgè nedidelį kiekị pacientų, kuriems buvo patvirtinta COVID-19 pneumonija ir tą pačią dieną atlikti UG ir krūtinès KT tyrimai. Analizejje matoma abiejų tyrimų vidutinio-didelio pozityvumo koreliacija, kuri buvo didelio reikšmingumo $(p<0,001)$, rodančio, 
jog ultragarso tyrimas yra ganėtinai informatyvus plaučių pažeidimo sunkumo vertinimui [7].

Plaučiu ultragarsas kitu virusiniu pandemiju metu. PUG tyrimo nauda pandemijos metu stebima jau ne pirmą kartą. Siaučiant 2009 metų influenza A (H1N1) pandemijai, atlikus krūtinès ląstos rentgenografijas dažnai nepavykdavo identifikuoti ankstyvos plaučių ligos [8]. Skerspjūvio tyrimo analizè atskleidè nenormalias ultragarsu matomas struktūras, rodančias intersticini sindromą 15 iš 16 pacientų, kuriems krūtinès rentgenograma pakitimų neparodè. Vèliau jiems buvo diagnozuota virusinè H1N1 (63\%) arba bakterinè (38 $\%$ ) pneumonija [9]. Nustatyta, jog plaučių ultragarsinio tyrimo jautrumas yra 94 proc., specifiškumas - 89 proc., teigiama nuspejjamoji vertė 86 proc., neigiama nuspejjamoji verte 96 procentai. Šis tyrimas pralenkè krūtinès ląstos rentgenografiją, aptinkant virusinę pneumoniją simptomus jaučiantiems pacientams [10].

Paukščiu gripo influenza A (H7N9) viruso plitimas 20132016 metais sukèlè didelę regioninę epidemiją Kinijoje. Jos metu dokumentuoti 1222 atvejai, kai mirštamumas siekè 40 procentų [11]. Plaučių ultragarso tyrimas, atliktas šiems pacientams, parodè pneumonijos ankstyvosios diagnostikos efektyvumą. Pacientams, kuriems galiausiai išsivystė ūminis kvèpavimo distreso sindromas (kaip infekcijos pasekmè), serijiniai plaučių UG tyrimai parodè B linijas, pleuros efuziją ir subpleurines konsolidacijas. Šie radiniai atitinka virusinių plaučių infekcijų, sukeltų H1N1 ar raupų viruso, radinius [12].

Standartizacija. Plaučių ultragarsas (PUG) ūminiam kvėpavimo nepakankamumui diagnozuoti naudojamas jau dešimtmečius. 2008 metais atliktame PUG tyrime prie paciento lovos (Bedside Lung Ultrasound in Emergency, sutr. BLUE) parodè 90,5 proc. tikslumą, diagnozuojant ūmaus kvėpavimo nepakankamumo priežastị kritiškai sunkios būklès ligoniams [13]. BLUE protokolo turi didesnis jautrumas, specifiškumas ir diagnostinis tikslumas pleuros efuzijoms, alveolinei konsolidacijai ir intersticiniam sindromui [14].

Naujoji COVID-19 infekcija parodè charakteringus patologinius pokyčius plaučiuose, todèl atsirado tyrimo standartizacijos poreikis, ypač kai reikia atsižvelgti ị esminius aspektus, tokius kaip daviklio parinkimas ir vaizdo nustatymu optimizavimas. Standartizavimo trūkumas išlieka viena didžiausių PUG efektyvumo kliūčių. COVID-19 pandemijos kontekste pasiekta pažangos ir buvo pristatytas pasiūlymas standartizacijai [15]. Pasiūlyta 4 lygių balų sistema su išsamiu vaizdo protokolu, kuris nusako vaizdo orientyrus, daviklius ir nustatymus, tokius kaip centrinio taško vieta ar mechaninis indeksas. 0 balas skiriamas esant pleuros linijai ir susijusiems horizontaliems artefaktams, iprastai vadinamiems A-linijomis. 1 balas asocijuojamas su pirmujų anomalijų atsiradimu. 2 balai siejami su nuo mažų iki didelių konsolidacijų atsiradimu. 3 balai skiriami atsiradus didelių, pailgejjusių vertikalių artefaktų, esant ar nesant stambių konsolidacijų [16].

PUG tyrimui atlikti reikalingų požymių išmanymas [20]. Pleuros linija UG tyrimo metu matoma kaip hiperechogeniška linija, kurią sudaro parietalinis ir visceralinis lapeliai. Pleura nuolat juda, todel tai yra dinaminis tyrimas [17]. Pleuros linija matoma kaip balta linija, apytiksliai 0,5 $\mathrm{cm}$ gylyje ị šonkaulio antkaulinị atspindi. Atsiradus pleuros efuzijai, visceralinès ir parietalinès pleuros paviršiai vienas nuo kito atskiriami skysčiu [18]. Pleuros linija patvirtinama M-režimu, kuriame stebimas ,jūros kranto“ požymis, atspindintis normalų pleuros slydimą [17].

A-linijos vaizdas sukuriamos nepažeistos, oringos plaučiu parenchimos. Tai yra aidejjimo artefaktai, atsirandantys dèl akustinio atspindžio tarp pleuros linijos ir ultragarso daviklio. Šios linijos yra normalus radinys sveikiems [19]. Jos gali būti dauginès, išsidèsčiusios reguliariais intervalais. A-linijos be slydimo leidžia ịtarti pneumotoraksą [20].

B-linijos yra dar vienas artefaktas, apibūdinamas kaip ilgos, gerai apibrezžtos, hiperechogeniškos linijos, kurios kyla iš pleuros linijos ir juda kartu su plaučiu slydimu [21]. B-linijos prasideda ties pleuros linija ir tęsiasi iki $8-10 \mathrm{~cm}$ gylio. Daugiau nei 3 B-linijos kiekviename plaučio lauke laikomos patologija. Šie artefaktai matomi kaip „kometos uodegos" ir savo trajektorijoje pašalina A-linijas. Manoma, kad tai iš dalies sumažèjęs plaučio oringumas, ar skysčio pripildytos tarpskiltelinès pertvaros. B-linijos yra dažniausias radinys kritiškai sunkios būklès COVID-19 pneumonija sergantiems ligoniams [22], jų kiekis bei sustorejjusi pleuros linija koreliuoja su būklès sunkumu [23].

Konsolidacijos nèra artefaktai, tai anatominiai radiniai, matomi kaip hipoechogeniniai plotai plaučio paviršiuje. Konsolidacija patvirtinama fraktalinio (angl. fractal), skiautės (angl. shred) ženklu ar hepatizacijos požymiu. Dauginès smulkios subpleurinès konsolidacijos pasiskirsto plaučių periferijoje. Žinant subpleurinių konsolidacijų skaičių, galima nuspèti ligos sunkumą ir prognozę, vietoje pasikliovimo vien B liniju skaičiavimu ir (ar) stambiu konsolidaciju buvimu, kurių COVID-19 pneumonijos atveju randama retai [24].

Pleuros efuzija matoma kaip homogeniškas, anechoiškas (kartais gali būti hipoechogeniškas) tarpas tarp parietalinès ir visceralinès pleuros. Šie tarpai formuojasi iškvėpimo metu, tačiau adhezija tarp abiejų pleuros lapelių gali sutrikdyti plaučio judejjimą [25]. Pleuros efuzija matoma M-režimu ir atpažistama vadinamu sinusoidiniu signalu. Sergančiujų COVID-19 pneumonija pleuros efuzijos yra mažos ir retos, išskyrus atvejus, kai paciento didelis skysčių balansas, esant staziniam širdies nepa- 
kankamumui, ar prisidejus bakterinei infekcijai [26]. Vis dar neaišku, ar su COVID-19 susijusios efuzijos tiesiogiai susijusios su SARS-CoV-2 infekcija [27].

PUG trūkumai. Plaučių ultragarso tyrimas neišvengiamai turi tam tikrų trūkumų, i kuriuos turi būti atsižvelgiama. PUG turi didelị jautrumą, tačiau jis reikalauja specifinio apmokymo, ribojamas labai mažo specifiškumo ir nepatikimos teigiamos nuspèjamosios vertès [28]. Artefaktinių B-linijų atsiradimas gali būti matomas ir esant kitų patologijų, tokių kaip plaučių edema, intersticiné fibrozè ir astma. B-linijos gali būti matomos ir sveikiems individams, todèl jos turetuc būti interpretuojamos atsižvelgiant ị paciento amžių. Kitas PUG trūkumas - negalèjimas prasiskverbti ị gilesnius plaučių parenchimos plotus, todèl visapusiam plaučių ištyrimui, norint nustatyti gilesnes jų pažaidas, tikslinga atlikti krūtinès KT tyrimą. [29]. Kai kurie autoriai teigia, jog nesenai paviešintose studijose UG nauda ir verte COVID-19 sukeltos pneumonijos diagnostikai ir stebejjimui yra perdèta [30].

\section{Išvados}

1. Nors PUG jautrumas yra didelis, tyrimo metu aptikti pakitimai nèra specifiški COVID-19 infekcijai.

COVID-19 sukeltai pneumonijai būdingas periferinis subpleurinių konsolidacijų pasiskirstymas, centrinèse plaučio skiltyse esantys pažeidimo plotai gali būti praleisti, todèl COVID-19 pneumonijos diagnostikos aukso standartu išlieka krūtinès KT.

2. Didelis COVID-19 infekcijos užkrečiamumo ir plitimo pavojus sunkina šios ligos diagnostiką. Dẻl galimybės atlikti tyrimą šalia paciento lovos, tyrimo greičio, kartojimo galimybès, didelio jautrumo, plaučių ultragarsinis tyrimas tapo kompiuterinès tomografijos alternatyva ligos diagnostikai ir stebejjimui.

\section{Literatūra}

1. Wu Z, McGoogan JM. Characteristics of and Important Lessons From the Coronavirus Disease 2019 (COVID-19) Outbreak in China: Summary of a Report of 72314 Cases From the Chinese Center for Disease Control and Prevention. JAMA 2020;323(13):1239-1242.

https://doi.org/10.1001/jama.2020.2648

2. Yasin R, Gouda WM. Chest X-ray findings monitoring COVID-19 disease course and severity. Egypt J Radiol Nucl Med 2020; 51(1): 193 https://doi.org/10.1186/s43055-020-00296-x

3. Zhao W, Zhong Z, Xie X, et al. Relation between chest CT Findings and clinical conditions of coronavirus disease (COVID-19) pneumonia: a multicenter study. Am J Roentgenol 2020;214(5):1072-1077.

https://doi.org/10.2214/AJR.20.22976
4. Giri AK, Rana DRSJB. Charting the challenges behind the testing of COVID-19 in developing countries: Nepal as a case study. Elsevier 2020; 2(2):53-56. https://doi.org/10.1016/j.bsheal.2020.05.002

5. Testa A, Soldati G, Copetti R, et al. Early recognition of the 2009 pandemic influenza A (H1N1) pneumonia by chest ultrasound. Crit Care 2012;16(1):R30. https://doi.org/10.1186/cc11201

6. Peixoto AO, Costa RM, Uzun R, Fraga AMA, Ribeiro JD, Marson FAL. Applicability of lung ultrasound in COVID-19 diagnosis and evaluation of the disease progression: A systematic review. Pulmonology 2021;27(6):529-562.

https://doi.org/10.1016/j.pulmoe.2021.02.004

7. Nouvenne A, Zani MD, Milanese G, Parise A, Baciarello M, Bignami EG, et al. Lung ultrasound in COVID-19 pneumonia: correlations with chest $\mathrm{CT}$ on hospital admission. Respiration 2020;99(7):617-624.

https://doi.org/10.1159/000509223

8. Agarwal PP, Cinti S, Kazerooni EA. Chest radiographic and CT findings in novel swine-origin influenza A (H1N1) virus (S-OIV) infection. Am J Roentgenol 2009;193(6):1488-1493. https://doi.org/10.2214/AJR.09.3599

9. Buonsenso D, Piano A, Raffaelli F, Bonadia N, de Gaetano Donati K, Franceschi F. Point-of-Care lung ultrasound findings in novel coronavirus disease-19 pnemoniae: a case report and potential applications during COVID-19 outbreak. Eur Rev Med Pharmacol Sci 2020;24(5):2776-2780.

10. Zhang YK, Li J, Yang JP, Zhan Y, Chen J. Lung ultrasonography for the diagnosis of 11 patients with acute respiratory distress syndrome due to bird flu H7N9 infection. Virol J 2015;12:176. https://doi.org/10.1186/s12985-015-0406-1

11. World Health Organization. Human infection with avian influenza A (H7N9) virus - China. 2017. https://www.who.int/csr/ don/01-may-2017-ah7n9-china/en/

12. Convissar DL, Gibson LE, Berra L, Bittner EA, Chang MG. Application of Lung Ultrasound During the COVID-19 Pandemic: A Narrative Review. Anesth Analg 2020;131(2):345-350. https://doi.org/10.1213/ANE.0000000000004929

13. Lichtenstein DA, Meziere GA. Relevance of lung ultrasound in the diagnosis of acute respiratory failure: the BLUE protocol. Chest 2008;134(1):117-25. https://doi.org/10.1378/chest.07-2800

14. Lichtenstein DA, Goldstein I, Mourgeon E, Cluzel P, Grenier P, Rouby JJ. Comparative diagnostic performances of auscultation, chest radiography, and lung ultrasonography in acute respiratory distress syndrome. Anesthesiology 2004;100(1):9-15. https://doi.org/10.1097/00000542-200401000-00006

15. Soldati G, Smargiassi A, Inchingolo R, Buonsenso D, Perrone T, Briganti DF, Perlini S, Torri E, Mariani A, Mossolani EE, Tursi F, Mento F, Demi L. Proposal for international standardization of the use of lung ultrasound for patients with COVID-19: A Simple, Quantitative, Reproducible Method. J Ultrasound Med 
2020;39(7):1413-1419.

https://doi.org/10.1002/jum. 15285

16. Dargent A, Chatelain E, Kreitmann L, Quenot JP, Cour M, Argaud L; COVID-LUS study group. Lung ultrasound score to monitor COVID-19 pneumonia progression in patients with ARDS. PLoS One 2020;15(7):e0236312.

https://doi.org/10.1371/journal.pone. 0236312

17. Mayo P, Broaddus VC, Finlay G. Bedside pleural ultrasonography: Equipment, technique, and the identification of pleural effusion and pneumothorax. UpToDate 2021;38:125-130.

18. Neto MJF, Rahal JA, Vieira FAC, Silva PSD, Funari MBG. Advances in lung ultrasound. Einstein (São Paulo) 2016;14(3):443-448.

https://doi.org/10.1590/S1679-45082016MD3557

19. Clevert DA. White Paper: Lung Ultrasound in Patients with Coronavirus COVID-19 Disease 2020. https://www.sieme ns-healthineers.com/fi/ultrasound/lung-ultrasound-covid-19.

20. Jackson K, Butler R, Aujayeb A. Lung ultrasound in the COVID-19 pandemic. Postgrad Med J 2021;97(1143):34-39. https://doi.org/10.1136/postgradmedj-2020-138137

21. Peng QY, Wang XT, Zhang LN; Chinese Critical Care Ultrasound Study Group (CCUSG). Findings of lung ultrasonography of novel corona virus pneumonia during the 2019-2020 epidemic. Intensive Care Med 2020;46(5):849-50.

https://doi.org/10.1007/s00134-020-05996-6

22. VanNatta K, Lieu E, Desai A, Southgate S, Freudenberger J, Liu R. Lung Ultrasound in COVID-19 2020. https://www.emra. org/emresident/article/lung-us-in-covid/.

23. Bitar ZI, Shamsah M, Maadarani OS, Bamasood OM, Bitar AZ, Alfoudri H. Lung Ultrasound and Sonographic Subpleural Consolidation in COVID-19 Pneumonia Correlate with Disease Severity. Crit Care Res Pract 2021;2021:6695033.

https://doi.org/10.1155/2021/6695033

24.Von Groote-Bidlingmaier F, Coenraad FN, Koegelenberg B. A practical guide to transthoracic ultrasound. Respiration 2012;9:132-142.

https://doi.org/10.1183/20734735.024112

25. Fahad AM, Al-Khalidi HA, Alhaideri YAA, Altimimi YQM, Alshewered AS. Pleural effusion in a patient with COVID-19 pneumonia and lung cancer: A case report. Respir Med Case Rep 2020;31:101302.

https://doi.org/10.1016/j.rmcr.2020.101302

26. Colombi D, Petrini M, Maffi G, Villani GD, Bodini FC, Morelli N, Milanese G, Silva M, Sverzellati N, Michieletti E. Comparison of admission chest computed tomography and lung ultrasound performance for diagnosis of COVID-19 pneumonia in populations with different disease prevalence. Eur J Radiol 2020;133:109344.

https://doi.org/10.1016/j.ejrad.2020.109344

27. Schoenfeld E, Budhram G. Introduction to Bedside Ultrasound: Volume 1. Emergency Ultrasound Solutions. Academic Emergency Medicine 2013;21(1):66-84.

28. Sofia S, Boccatonda A, Montanari M, Spampinato M, D'ardes D, Cocco G, Accogli E, Cipollone F, Schiavone C. Thoracic ultrasound and SARS-COVID-19: a pictorial essay. J Ultrasound 2020;23(2): 217-221.

https://doi.org/10.1007/s40477-020-00458-7

29. Huang Y, Wang S, Liu Y, et al. A preliminary study on the ultrasonic manifestations of peripulmonary lesions of non-critical novel coronavirus pneumonia (COVID-19). 2020:3544750. https://doi.org/10.21203/rs.2.24369/v1

30. Khalili N, Haseli S, Iranpour P. Lung Ultrasound in COVID-19 Pneumonia: Prospects and Limitations. Acad Radiol 2020;27(7):1044-1045.

https://doi.org/10.1016/j.acra.2020.04.032

\section{THE USE OF LUNG ULTRASOUND IN COVID-19 INDUCED PNEUMONIA \\ D. Vingrys, U. Kulnickaitė}

Keywords: COVID-19, lung ultrasound, pneumonija.

Summary

SARS-CoV-2 virus caused COVID-19 infection mainly damages the breathing system and characterises with high virulency. This complicated diagnostic possibilities and transportation of the patients. These problems lead to a search of alternative diagnostic measures, which could reduce the spreading of the disease.

Aim. To find out the use of lung ultrasound in COVID-19 caused pneumonia diagnostics and follow-up for today.

Material and methods. With the help of PubMed database a review of literature was performed selecting publications which studied the use of lung ultrasound in COVID-19 pneumonia, findings, other viral pneumonias and comparison with computed tomography.

Ultrasound examination is known for its portability, short examination time, re-examination possibility, high sensitivity for changes in lung diseases. Due to these advantages ultrasound was inevitably put into use for diagnostics for COVID-19 caused pneumonia.

Correspondence to: domantas.vingrys@gmail.com

Gauta 2021-05-14 